
\title{
$\begin{array}{ll}\text { Research Square } & \begin{array}{l}\text { Preprints are preliminary reports that have not undergone peer review. } \\ \text { They should not be considered conclusive, used to inform clinical practice, } \\ \text { or referenced by the media as validated information. }\end{array}\end{array}$
}

\section{Seroprevalence and associated risk factors of Toxocara canis infection among primary schoolchildren from rural areas of southern Thailand}

Nonthapan Phasuk

Walailak University School of Medicine

Chuchard Punsawad ( $\nabla$ chuchard.pu@wu.ac.th )

Walailak University School of Medicine https://orcid.org/0000-0003-4826-9474

Research article

Keywords: Seroprevalence, Toxocara canis, Schoolchildren, southern Thailand

Posted Date: January 16th, 2020

DOI: https://doi.org/10.21203/rs.2.20999/v1

License: (c) (i) This work is licensed under a Creative Commons Attribution 4.0 International License. Read Full License 


\section{Abstract}

\section{Background}

Human toxocariasis is a parasitic zoonosis caused by a parasite in the genus Toxocara and is transmitted mainly by accidental ingestion of embryonated Toxocara canis (dog round worm) or T. cati (cat round worm) eggs. Several studies reported that children were the main population at risk for T. canis infection. Currently, no reports on the seroprevalence of $T$. canis infection in Thailand are available, and its status remains unknown among children who live in rural areas of southern Thailand.

\section{Objective}

This study aimed to investigate the seroprevalence of $T$. canis infection and its associated risk factors among primary schoolchildren in rural areas of Nakhon Si Thammarat Province, Thailand.

\section{Methods}

A total of 177 schoolchildren between 6 and 13 years of age were recruited between June and July 2019. Serum anti-T. canis IgG antibodies were detected with a commercial ELISA kit. A questionnaire administered by direct interviews was used to collect demographic and behavioral risk factor data.

\section{Results}

The overall seroprevalence of $T$. canis infection was 58.2\% (103 of 177). The univariate analysis revealed that schoolchildren who did not practice handwashing before a meal (crude odds ratio (COR) $=3.67,95 \% \mathrm{Cl}$ : 1.93-6.95, $P<$ $0.001)$, did not practice hand washing after animal contact (COR $=2.89,95 \% \mathrm{Cl}: 1.53-5.47, P=0.001)$, and drank untreated water $(\mathrm{COR}=1.87,95 \% \mathrm{Cl}: 1.00-3.48, P=0.049)$ had an increased risk of acquiring $T$. canis infection. However, after adjusting for confounders, only a lack of handwashing before a meal remained a significant risk factor (adjusted odds ratio $(A O R)=2.20,95 \% \mathrm{Cl}: 1.11-4.34, P=0.023$ ). Age, sex, owning a dog and eating fresh vegetables were not significantly associated with $T$. canis infection in the current study.

\section{Conclusions}

This is the first serological investigation of T. canis infection among schoolchildren in Thailand. The high rate of Toxocara seropositivity reflected high levels of exposure to T. canis among schoolchildren in rural areas of southern Thailand. The results also provide baseline data regarding modifiable risk behaviors for effective $T$. canis infection prevention strategies in southern Thailand, especially strengthening hand washing practices among schoolchildren.

\section{Introduction}

Human toxocariasis is one of most prevalent parasitic zoonoses worldwide; it is particularly present in subtropical and tropical regions and in developing countries [1]. Toxocariasis is caused by nematode parasites of the genus Toxocara, including dog roundworms (Toxocara canis) and cat roundworms (Toxocara cati), whose definitive hosts are dogs and cats, respectively [2]. Humans acquire Toxocara spp. via the accidental consumption of Toxocara eggs, which are present in soil contaminated by dog/cat feces, or via ingestion of larvae in undercooked meat [2]. Clinical manifestations of human toxocariasis are mostly asymptomatic; however, severe disease can occur when larvae 
migrate within the body to internal organs or the eyes, causing visceral toxocariasis and ocular toxocariasis, respectively [1].

Humans are incidental hosts for Toxocara spp. The larvae cannot develop into adult worms in the human small intestine; thus, no Toxocara eggs are present in human stool [3]. The typical diagnosis of toxocariasis usually relies on serological tests. Enzyme-linked immunosorbent assay (ELISA) using Toxocara excretory-secretory (TES) antigens has been widely used and recommended by the Centers for Disease Control and Prevention to detect a Toxocara-specific $\lg [3,4]$. The limitations of this test are its cross-reactivity with other parasites, especially the human roundworm, Ascaris lumbricoides [5], and its lack of ability to differentiate between active and past infections. However, ELISA remains useful in seroepidermiological surveys, as it is quick in determining the prevalence of asymptomatic toxocariasis and affordable.

Seroprevalence studies have been performed in several countries around the world. In some parts of the world, such as Nigeria (86.1\%) [6], the Republic of the Marshall Islands (86.75\%), [7] and Northeast Brazil (63.6\%) [8], the seroprevalence of toxocariasis was remarkably high. In Asia, the seroprevalence of toxocariasis was substantially high, at $46.0 \%$ in Taiwan [9], 45.9\% in Turkey [10], 49\% in the Philippines [11], 51.2\% in Korea, and 23.5\% - 45.9\% in Iran [12, 13]. In Western countries, the prevalence was 5.0\% in the United States [14], 8.0\% in Italy [15] and 16.0\% in Greece [16]. Many factors have been proposed to be involved, including contact with dogs [8, 12], children's age [17] and male sex [8, $18,19]$.

In Thailand, previous reports revealed that Toxocara eggs were found in the stool of dogs and cats [20, 21]. Furthermore, Toxocara eggs were identified in raw vegetables from the markets in southern Thailand [22]; however, its impact on humans has not been investigated. In this study, we aimed to assess the seroprevalence and associated risk factors of Toxocara canis infection among schoolchildren in rural areas of southern Thailand.

\section{Methods}

\section{Study design and setting}

This cross-sectional study was carried out from June to July 2019 in five districts of Nakhon Si Thammarat Province, including Phrom Khiri, Tha Sala, Sichon, Khanom and Nopphitam. Nakhon Si Thammarat Province is located in southern Thailand, approximately 780 kilometers from the Thai capital of Bangkok ( $\left.8^{\circ} 25^{\prime} 7^{\prime \prime} \mathrm{N} 99^{\circ} 57^{\prime} 49^{\prime \prime} \mathrm{E}\right)$ (Figure 1). The average temperature is $27.1^{\circ} \mathrm{C}$, with a low temperature of $25.8^{\circ} \mathrm{C}$ in January and a high temperature of $29.3^{\circ} \mathrm{C}$ in May. The annual rainfall is $1,454.3 \mathrm{~mm}$ (Climatological Center, Thai Meteorological Department). The Thailand Department of Provincial Administration estimates that the total populations of the subdistricts were 27,302 in Phrom Khiri, 113,323 in Tha Sala, 81,888 in Sichon, 20,369 in Khanom and 33,543 in Nopphitam. The five districts are similar in terms of culture, economic status and climate.

\section{Study population and sample size}

The study population consisted of primary schoolchildren from 7 to 13 years of age. The sample size was determined using the single proportion population formula:

$Z^{2} p(1-p) / d^{2}$

where $p=$ prevalence of intestinal parasites from a previous study, $d=$ margin of error, and $Z$ = standard score, which corresponds to 1.96 . This formula was calculated based on a prevalence rate of $86.75 \%$ from a previous study [7], with 
a margin of error of 0.05 and a confidence level of $95 \%$. An appropriate sample size was determined to be 177 . Students who had immune system disorders (such as autoimmune disorders and acquired immune deficiency syndrome), who were on steroid treatment for at least 3 months and who had acute diseases on the day of blood collection were excluded from the study. Three schools were randomly selected from each district for a total of fifteen schools. Finally, the participants were selected from the school rosters using a systematic random sampling technique in which every $10^{\text {th }}$ person was included in the study.

\section{Questionnaire survey}

A structured questionnaire was developed and used to collect demographic data (i.e., age, sex, and parental education and occupation) and information on possible risk factors (habits of handwashing before a meal, after playing and after animal contact; owning pets (dogs or cats); eating fresh vegetables; and drinking untreated water). Agriculturists, farm laborers, housemaids, fishing boat staff, and street vendors were considered nonskilled workers. The questionnaire was administered by two trained interviewers who conducted direct interviews with the participating schoolchildren.

\section{Blood collection and preparation}

Blood samples were collected from the antecubital vein by medical technologists and kept for 45 min at room temperature. After that, serum was separated by centrifugation at $2500 \mathrm{rpm}$ for 10 minutes and stored at $-80^{\circ} \mathrm{C}$ until measurement of IgG class antibodies against T. canis.

\section{Detection of anti-T. canis IgG antibodies}

Serum anti-T. canis IgG antibodies were detected with a commercial ELISA kit (Abcam, UK) according to the manufacturer's instructions. In brief, all samples were diluted to 1:100 with lgG sample diluent, and all controls ( $T$. canis IgG-positive, T. canis IgG-negative and T. canis IgG cutoff (CO)) were prepared. A precoated plate was incubated (100 $\mu \mathrm{L} /$ well) with control or diluted samples and incubated for 1 hour at $37^{\circ} \mathrm{C}$. After incubation with the serum samples, the plates were washed 3 times with $1 x$ washing solution and incubated (100 $\mu \mathrm{L} /$ well) with protein A HRP conjugate for 30 minutes at room temperature. The plates were washed 3 times and incubated (100 $\mu \mathrm{L} /$ well) with TMB substrate solution for exactly 15 minutes at room temperature in the dark. The reaction was stopped (100 $\mu \mathrm{L} /$ well) with stop solution for 15 minutes at room temperature. The assay included negative and positive serum samples in addition to a blank (no serum sample). Absorbance at $492 \mathrm{~nm}$ was measured using an automatic microplate reader. For interpretation of the results, samples with an absorbance value of more than $10 \%$ above the CO were considered positive. If the absorbance value was between $10 \%$ above and $10 \%$ below the $\mathrm{CO}$, it was considered inconclusive (in the gray zone), and a fresh sample was run again. If the results of the second test were less than $10 \%$ above or below the CO control value, the sample was considered negative.

\section{Data analysis}

Data were entered, cleaned, and analyzed using IBM SPSS Statistics for Windows, Version 23. Quantitative variables were described by medians and interquartile ranges (IQRs), and qualitative variables were described by frequencies (percentages). A chi-square test was used to compare the proportions of $T$. canis infection with sex, age group, level of education, districts, parental occupation and parental education. A univariate logistic regression model was constructed to investigate risk factors associated with $T$. canis infection. The variables with $P$-values less than 0.2 in the univariate 
logistic regression model were included in a multiple logistic regression model to adjust for confounding factors.

Differences were considered to be statistically significant when the $P$-value obtained was less than 0.05 .

\section{Results}

\section{Sociodemographic characteristics}

A total of 177 schoolchildren (91 boys and 87 girls) from five districts were included in this study. The median age of the study population was 9.82 years (IQR 9-11 years). The enrolled schoolchildren resided in 5 districts of Nakhon Si Thammarat, including Khanom $(n=35)$, Sichon $(n=34)$, Phrom Kiri $(n=34)$, Nopphitam $(n=36)$, and Thasala $(n=38)$.

Their parents' occupation and education level were mostly nonskilled workers and completion of high school or less, respectively (Table 1).

\section{Seroprevalence of Toxocara canis infection}

The overall seroprevalence of $T$. canis infection among the participants was $58.2 \%$ (95\% Cl: $50.9-65.5)$. Boys had a higher seropositive rate $(64.8 \%)$ than girls $(51.2 \%)$. The rates of seropositivity $(54.3 \%$ in Khanom, $52.9 \%$ in Sichon, $58.8 \%$ in Phrom Kiri, 55.6\% in Nopphitam and 68.4\% in Thasala) were not significantly different among the five districts $(P=0.672)$. The highest seropositivity was observed among third-grade students $(68.3 \%)$, followed by sixth-grade students $(65.0 \%)$, while the lowest rate was observed among fourth-grade students (43.8\%). Chi-square tests showed that there were no significant associations between $T$. canis infection and sex, age group, level of education, district, parents' occupation and education (Table 1).

Table 1. Sociodemographic characteristics of 177 schoolchildren in $\mathbf{5}$ districts of Nakhon Si Thammarat, Thailand 


\begin{tabular}{|c|c|c|c|c|}
\hline \multirow[t]{2}{*}{ Characteristics } & & \multicolumn{3}{|c|}{ Seropositive } \\
\hline & & Number & $\%$ & $P$-value \\
\hline \multirow[t]{2}{*}{ Sex } & Male $(\mathrm{n}=91)$ & 59 & 64.8 & \multirow[t]{2}{*}{0.065} \\
\hline & Female $(n=86)$ & 44 & 51.2 & \\
\hline \multirow[t]{3}{*}{ Age group (years) } & $6-8(n=32)$ & 18 & 56.3 & \multirow[t]{3}{*}{0.970} \\
\hline & $9-10(n=82)$ & 48 & 58.5 & \\
\hline & $11-13(n=63)$ & 37 & 58.7 & \\
\hline \multirow[t]{6}{*}{ Level of education (grade) } & $1(n=15)$ & 8 & 53.3 & \multirow[t]{6}{*}{0.256} \\
\hline & $2(n=17)$ & 11 & 64.7 & \\
\hline & $3(n=41)$ & 28 & 68.3 & \\
\hline & $4(n=32)$ & 14 & 43.8 & \\
\hline & $5(n=32)$ & 16 & 50.0 & \\
\hline & $6(n=40)$ & 26 & 65.0 & \\
\hline \multirow[t]{5}{*}{ Districts } & Khanom $(\mathrm{n}=35)$ & 19 & 54.3 & \multirow[t]{5}{*}{0.672} \\
\hline & Sichon $(n=34)$ & 18 & 52.9 & \\
\hline & Phrom Kiri $(n=34)$ & 20 & 58.8 & \\
\hline & Nopphitam (n = 36) & 20 & 55.6 & \\
\hline & Thasala $(n=38)$ & 26 & 68.4 & \\
\hline \multirow[t]{2}{*}{ Father's occupation } & Nonskilled workers $(n=165)$ & 98 & 59.4 & \multirow[t]{2}{*}{0.229} \\
\hline & Skilled workers $(n=12)$ & 5 & 41.7 & \\
\hline \multirow[t]{2}{*}{ Mother's occupation } & Nonskilled workers $(n=163)$ & 96 & 58.9 & 0.517 \\
\hline & Skilled workers $(n=14)$ & 7 & 50.0 & \\
\hline \multirow[t]{2}{*}{ Father's education } & High school or less $(n=160)$ & 96 & 60.0 & 0.135 \\
\hline & Bachelor's degree or more $(n=17)$ & 7 & 41.2 & \\
\hline \multirow[t]{2}{*}{ Mother's education } & High school or less ( $n=159)$ & 96 & 60.4 & 0.080 \\
\hline & Bachelor's degree or more $(n=18)$ & 7 & 38.9 & \\
\hline Total $(n=177)$ & & 103 & 58.2 & \\
\hline
\end{tabular}

\section{Associated risk factors for Toxocara canis infections}

The univariate analysis revealed that handwashing before a meal, hand washing after animal contact and drinking untreated water were significantly associated with seropositivity for $T$. canis. However, the multivariate analysis indicated that handwashing before a meal was the only factor associated with $T$. canis seropositivity. Children who did 
not practice handwashing before a meal were more likely to be infected with $T$. canis than those who did $(A O R=2.20$, 95\% Cl: 1.11-4.34) (Table 2).

When stratified by age, the rates of seropositivity for T. canis were approximately equal among age groups (56.3\%, $58.5 \%$ and $58.7 \%$ for children $6-8$ years of age, $9-10$ years of age and $11-13$ years of age, respectively). Boys were more likely to be infected with $T$. canis than girls. Children who did not practice hand washing after playing as well as children who owned dogs and cats and who ate fresh vegetables were more likely to be infected with $T$. canis than those who did not. However, there was no statistical significance among these factors in both the univariate and multivariate analyses (Table 2).

Table 2. Factors associated with $T$. canis infection among primary schoolchildren from rural areas of southern Thailand 


\begin{tabular}{|c|c|c|c|c|c|c|c|c|c|c|}
\hline Variables & & $\begin{array}{l}\text { Number } \\
\text { (\%) }\end{array}$ & $\begin{array}{l}\text { No. } \\
\text { positive } \\
\text { (\%) }\end{array}$ & $\begin{array}{l}\text { No. } \\
\text { negative } \\
(\%)\end{array}$ & COR & $\begin{array}{l}95 \% \\
\mathrm{Cl}\end{array}$ & $P$-value & AOR & $\begin{array}{l}95 \% \\
\mathrm{Cl}\end{array}$ & $P$-value \\
\hline \multirow[t]{3}{*}{$\begin{array}{l}\text { Age } \\
\text { (years) }\end{array}$} & $6-8$ & $\begin{array}{l}32 \\
(18.1)\end{array}$ & $\begin{array}{l}18 \\
(56.3)\end{array}$ & $\begin{array}{l}14 \\
(43.8)\end{array}$ & 1 & & & & & \\
\hline & $9-10$ & $\begin{array}{l}82 \\
(46.3)\end{array}$ & $\begin{array}{l}48 \\
(58.5)\end{array}$ & $\begin{array}{l}34 \\
(41.5)\end{array}$ & 1.10 & $\begin{array}{l}0.48- \\
2.51\end{array}$ & 0.824 & & & \\
\hline & $11-13$ & $\begin{array}{l}63 \\
(35.6)\end{array}$ & $\begin{array}{l}37 \\
(58.7)\end{array}$ & $\begin{array}{l}26 \\
(41.3)\end{array}$ & 1.11 & $\begin{array}{l}0.47- \\
2.62\end{array}$ & 0.817 & & & \\
\hline \multirow[t]{2}{*}{ Sex } & Male & $\begin{array}{l}91 \\
(51.4)\end{array}$ & $\begin{array}{l}59 \\
(64.8)\end{array}$ & $\begin{array}{l}32 \\
(35.2)\end{array}$ & 1.76 & $\begin{array}{l}0.96- \\
3.22\end{array}$ & 0.066 & 1.04 & $\begin{array}{l}0.57- \\
1.89\end{array}$ & 0.910 \\
\hline & Female & $\begin{array}{l}86 \\
(48.6)\end{array}$ & $\begin{array}{l}44 \\
(51.2)\end{array}$ & $\begin{array}{l}42 \\
(48.8)\end{array}$ & 1 & & & & & \\
\hline \multirow{2}{*}{$\begin{array}{l}\text { Hand } \\
\text { washing } \\
\text { before a } \\
\text { meal }\end{array}$} & Yes & $\begin{array}{l}224 \\
(74.9)\end{array}$ & $19(8.5)$ & $\begin{array}{l}205 \\
(91.5)\end{array}$ & 1 & & & & & \\
\hline & No & $\begin{array}{l}75 \\
(25.1)\end{array}$ & $\begin{array}{l}13 \\
(17.3)\end{array}$ & $\begin{array}{l}62 \\
(82.7)\end{array}$ & 3.67 & $\begin{array}{l}1.93- \\
6.95\end{array}$ & $<0.001^{\star}$ & 2.20 & $\begin{array}{l}1.11- \\
4.34\end{array}$ & $0.023^{\star}$ \\
\hline \multirow{2}{*}{$\begin{array}{l}\text { Hand } \\
\text { washing } \\
\text { after } \\
\text { playing }\end{array}$} & Yes & $\begin{array}{l}102 \\
(57.6)\end{array}$ & $\begin{array}{l}56 \\
(54.9)\end{array}$ & $\begin{array}{l}46 \\
(45.1)\end{array}$ & 1 & & & & & \\
\hline & No & $\begin{array}{l}75 \\
(42.4)\end{array}$ & $\begin{array}{l}47 \\
(62.7)\end{array}$ & $\begin{array}{l}28 \\
(37.3)\end{array}$ & 1.38 & $\begin{array}{l}0.75- \\
2.54\end{array}$ & 0.301 & & & \\
\hline \multirow{2}{*}{$\begin{array}{l}\text { Hand } \\
\text { washing } \\
\text { after } \\
\text { animal } \\
\text { contact }\end{array}$} & Yes & $\begin{array}{l}101 \\
(57.1)\end{array}$ & $\begin{array}{l}48 \\
(47.5)\end{array}$ & $\begin{array}{l}53 \\
(52.5)\end{array}$ & & & & & & \\
\hline & No & $\begin{array}{l}76 \\
(42.9)\end{array}$ & $\begin{array}{l}55 \\
(72.4)\end{array}$ & $\begin{array}{l}21 \\
(27.6)\end{array}$ & 2.89 & $\begin{array}{l}1.53- \\
5.47\end{array}$ & $0.001 *$ & 1.686 & $\begin{array}{l}0.83- \\
3.44\end{array}$ & 0.150 \\
\hline \multirow[t]{2}{*}{$\begin{array}{l}\text { Owning } \\
\text { dogs }\end{array}$} & Yes & $\begin{array}{l}71 \\
(40.1)\end{array}$ & $\begin{array}{l}37 \\
(52.1)\end{array}$ & $\begin{array}{l}34 \\
(47.9)\end{array}$ & 1.52 & $\begin{array}{l}0.83- \\
2.79\end{array}$ & 0.180 & 1.129 & $\begin{array}{l}0.53- \\
2.41\end{array}$ & 0.754 \\
\hline & No & $\begin{array}{l}106 \\
(59.9)\end{array}$ & $\begin{array}{l}66 \\
(62.3)\end{array}$ & $\begin{array}{l}40 \\
(37.7)\end{array}$ & & & & & & \\
\hline \multirow[t]{2}{*}{$\begin{array}{l}\text { Owning } \\
\text { cats }\end{array}$} & Yes & $\begin{array}{l}73 \\
(41.2)\end{array}$ & $\begin{array}{l}46 \\
(63.0)\end{array}$ & $\begin{array}{l}27 \\
(37.0)\end{array}$ & 1.41 & $\begin{array}{l}0.76- \\
2.59\end{array}$ & 0.277 & & & \\
\hline & No & $\begin{array}{l}104 \\
(58.8)\end{array}$ & $\begin{array}{l}57 \\
(54.8)\end{array}$ & $\begin{array}{l}47 \\
(45.2)\end{array}$ & 1 & & & & & \\
\hline \multirow{3}{*}{$\begin{array}{l}\text { Frequency } \\
\text { of dog } \\
\text { playing }\end{array}$} & Never & $\begin{array}{l}72 \\
(40.7)\end{array}$ & $\begin{array}{l}37 \\
(51.4)\end{array}$ & $\begin{array}{l}35 \\
(48.6)\end{array}$ & 1 & & & & & \\
\hline & $\begin{array}{l}1-2 \\
\text { times/week }\end{array}$ & $\begin{array}{l}53 \\
(29.9)\end{array}$ & $\begin{array}{l}34 \\
(64.2)\end{array}$ & $\begin{array}{l}19 \\
(35.9)\end{array}$ & 1.69 & $\begin{array}{l}0.82- \\
3.50\end{array}$ & 0.156 & 1.012 & $\begin{array}{l}0.45- \\
2.27\end{array}$ & 0.978 \\
\hline & $\begin{array}{l}3-4 \\
\text { times/week }\end{array}$ & $\begin{array}{l}22 \\
(12.4)\end{array}$ & $\begin{array}{l}16 \\
(72.7)\end{array}$ & $6(27.3)$ & 2.52 & $\begin{array}{l}0.89- \\
7.18\end{array}$ & 0.083 & 1.258 & $\begin{array}{l}0.37- \\
4.26\end{array}$ & 0.712 \\
\hline
\end{tabular}




\begin{tabular}{|c|c|c|c|c|c|c|c|c|c|c|}
\hline \multirow[t]{2}{*}{ Variables } & & $\begin{array}{l}\text { Number } \\
\text { (\%) }\end{array}$ & $\begin{array}{l}\text { No. } \\
\text { positive } \\
(\%)\end{array}$ & $\begin{array}{l}\text { No. } \\
\text { negative } \\
(\%)\end{array}$ & COR & $\begin{array}{l}95 \% \\
\mathrm{Cl}\end{array}$ & $P$-value & AOR & $\begin{array}{l}95 \% \\
\mathrm{Cl}\end{array}$ & $P$-value \\
\hline & $\begin{array}{l}5-7 \\
\text { times/week }\end{array}$ & $\begin{array}{l}30 \\
(16.9)\end{array}$ & $\begin{array}{l}16 \\
(53.3)\end{array}$ & $\begin{array}{l}14 \\
(46.6)\end{array}$ & 1.08 & $\begin{array}{l}0.46- \\
2.54\end{array}$ & 0.858 & 0.599 & $\begin{array}{l}0.21- \\
1.68\end{array}$ & 0.330 \\
\hline \multirow{2}{*}{$\begin{array}{l}\text { Eating } \\
\text { fresh } \\
\text { vegetables }\end{array}$} & Yes & $\begin{array}{l}36 \\
(20.3)\end{array}$ & $\begin{array}{l}19 \\
(52.8)\end{array}$ & $\begin{array}{l}17 \\
(47.2)\end{array}$ & 1.32 & $\begin{array}{l}0.63- \\
2.75\end{array}$ & 0.461 & & & \\
\hline & No & $\begin{array}{l}141 \\
(79.7)\end{array}$ & $\begin{array}{l}84 \\
(59.6)\end{array}$ & $\begin{array}{l}57 \\
(40.4)\end{array}$ & 1 & & & & & \\
\hline \multirow{2}{*}{$\begin{array}{l}\text { Drinking } \\
\text { untreated } \\
\text { water }\end{array}$} & Yes & $\begin{array}{l}113 \\
(63.8)\end{array}$ & $\begin{array}{l}72 \\
(63.7)\end{array}$ & $\begin{array}{l}41 \\
(36.3)\end{array}$ & 1.87 & $\begin{array}{l}1.00- \\
3.48\end{array}$ & $0.049^{*}$ & 1.429 & $\begin{array}{l}0.69- \\
2.96\end{array}$ & 0.338 \\
\hline & No & $\begin{array}{l}64 \\
(36.2)\end{array}$ & $\begin{array}{l}31 \\
(48.4)\end{array}$ & $\begin{array}{l}33 \\
(51.6)\end{array}$ & 1 & & & & & \\
\hline
\end{tabular}

* Significant association

COR: Crude odds ratio, AOR: adjusted odds ratio, Cl: 95\% confidence interval

\section{Discussion}

Toxocariasis is a prevalent parasitic zoonosis worldwide, especially in the tropics and subtropics. This study was the first serological investigation of $T$. canis infection among schoolchildren in southern Thailand, with a rate of $58.2 \%$. The rate of $T$. canis infection in this study was slightly higher than those in other countries in Asia, including the Philippines (49.0\%) [11], Taiwan (57.5\%) [23], Turkey (45.9\%) [10], Korea (51.2\%) [24] and Isfahan, Iran (45.9\%) [13], whereas the rate was lower than those in some other parts of the world, including Nigeria (86.1\%) [6] and the Republic of the Marshall Islands (86.8\%) [7]. In general, multiple factors, including environmental, geographic, cultural and socioeconomic factors, contribute to the magnitude of $T$. canis infection. Our study areas included five districts of Nakhon $\mathrm{Si}$ Thammarat Province, which were considered rural, where most of the countryside contains rubber plantations and farmlands, and where dogs are commonly owned as pets; moreover, there is a great number of stray dogs in these rural districts. Nakhon Si Thammarat has a tropical rainforest climate, in which the temperature ranges from 24 to $34^{\circ} \mathrm{C}$, which is suitable for the development of Toxocara eggs to the infective larval stage [25]. We hypothesized that climate, soil and the number of dogs in the areas influenced the rate of seropositivity in this study.

Among the five districts, Thasala showed the highest rate of Toxocara seropositivity (68.4\%); however, there was no statistically significant difference among the five districts. This might be explained by the similarities in climate, geography and culture among the districts. Children whose parents were nonskilled workers and had low education levels had an increased rate of Toxocara seropositivity. This trend was also observed in a previous study in the Republic of the Marshall Islands [7]. However, parents' education levels and occupations did not significantly affect the seroprevalence rate in this study. This might be due to a small number of children whose parents were skilled workers and obtained Bachelor's degrees.

Among the age groups, there was no significant difference in the rate of Toxocara seropositivity in the current study. The rates of Toxocara seropositivity were approximately similar across all age groups: $56.3 \%$ in children $6-8$ years of age, $58.5 \%$ in children $9-10$ years of age and $58.7 \%$ in children $11-13$ years of age. Similar findings were observed in the study from the Republic of the Marshall Islands [7]. However, this result was in contrast to results of several studies among schoolchildren that showed that older age was a significant risk factor for $T$. canis infection $[6,12,18,26,27]$. 
The detection of Toxocara via serology increases over time because of the persistence of serum IgG. The possible explanation for the similar seropositivity rates among the different age groups might be that the children might have been in contact with Toxocara eggs since a young age and the persistence of an IgG remains over a long period of time. Our study revealed that boys tended to be infected with Toxocara spp. more often than girls (64.8\% in boys and $51.2 \%$ in girls). This trend was also observed in previous studies $[8,18,19]$; it has been hypothesized that boys engage in more outdoor activities than girls; thus, they are more likely to be in contact with soil and dogs. However, sex was not significantly associated with Toxocara seropositivity in either the univariate or multivariate analysis in the current study.

Regarding modifiable risk behaviors, hand washing before a meal appeared to be the only significant risk factor associated with Toxocara infection in both the univariate and multivariate analyses. Schoolchildren who did not practice hand washing before a meal were 2.2 times more likely to be infected with T. canis than those who did. This effect was also observed in a previous study among Brazilian schoolchildren [28]. Furthermore, the univariate analysis in this study revealed that hand washing after animal contact and drinking untreated water were significantly associated with T. canis infection; however, these associations were not statistically significant in the multivariate analysis. Humans acquire T. canis by ingesting infective eggs. This study emphasizes the importance of hand hygiene to prevent parasite eggs from entering the body. Despite the report of Toxocara egg contamination in raw vegetables in Nakhon Si Thammarat Province in a previous study [22], eating fresh vegetables was not significantly associated with T. canis infection in the current study. This may be explained by the small number of schoolchildren who ate fresh vegetables 36 (20.3\%); thus, contamination from vegetables was not a likely route of transmission among these children. Schoolchildren who engaged in risk behaviors, such as owning dogs and owning cats, also tended to have a higher rate of $T$. canis infection than those who did not; however, no significant associations were observed among these factors and T. canis infection.

This study had the following limitations. First, the method for detection of anti-T. canis IgG antibodies was the ELISA technique, which could yield false positive results due its cross-reactivity with other helminths, especially $A$. Iumbricoides [5, 29]. However, our study sites were not endemic areas for $A$. lumbricoides $[30,31]$; hence, the chance of false positivity was likely low. Second, the study design was cross-sectional, and seroprevalence and risk factors were evaluated simultaneously, not over a period of time; thus, true causes and effects might not be strongly demonstrated.

\section{Conclusions}

This is the first serological investigation of T. canis infection among schoolchildren in Thailand. The high rate of Toxocara seropositivity reflected high levels of exposure to T. canis among schoolchildren in rural areas of southern Thailand. A lack of hand washing before meals appeared to be a significant risk factor for T. canis infection. Appropriate public health education on personal hygiene, especially strengthening hand hygiene practices among schoolchildren, should be implemented to prevent the transmission of $T$. canis.

\section{List Of Abbreviations}

AOR: adjusted odds ratio

Cl: confidence interval

CO: cut-off

COR: crude odds ratio

IQR: interquartile range 


\section{Declarations}

\section{Ethics approval and consent to participate}

The study was reviewed and approved by the Ethics Committee on Human Rights Related to Research Involving Human Subjects, Walailak University, prior to the recruitment of participants (WUEC-18-131-01). All participants and relevant parties were informed of the purpose of the study. Written informed consent was obtained from the parents or legal guardians of the children after clearly explaining the research objectives.

\section{Consent for publication}

Not applicable.

\section{Availability of data and materials}

All data generated or analyzed during this study are available from the corresponding author on reasonable request.

\section{Competing interests}

The authors declare that they have no competing interests.

\section{Funding}

This study was funded by Walailak University for financial support for this research (WU-IRG-62-009). The funder had no role in study design, data collection and analysis, decision to publish, or preparation of the manuscript.

\section{Authors' contributions}

$\mathrm{CP}$ and NP conceived and designed the study and performed data collection. CP performed experiments. CP, and NP analyzed the data. CP and NP wrote the manuscript. Both authors read and approved the final manuscript.

\section{Acknowledgments}

The authors wish to thank the schoolchildren from the five districts of Nakhon Si Thammarat Province, including Phrom Khiri, Tha Sala, Sichon, Khanom and Nopphitam, who participated in the study. The authors would like to acknowledge the directors and the teachers of the fifteen schools for their support throughout the course of this study. This research was partially supported by the New Strategic Research (P2P) project, Walailak University, Thailand.

\section{References}

1.Ma G, Holland CV, Wang T, Hofmann A, Fan CK, Maizels RM, Hotez PJ, Gasser RB: Human toxocariasis. Lancet Infect Dis 2018, 18(1):e14-e24.

2.Chen J, Liu Q, Liu GH, Zheng WB, Hong SJ, Sugiyama H, Zhu XQ, Elsheikha HM: Toxocariasis: a silent threat with a progressive public health impact. Infect Dis Poverty 2018, 7(1):59. 
3.Toxocariasis [https://www.cdc.gov/dpdx/toxocariasis/index.html] Accessed 12 Dec 2019.

4.Boldis V, Ondriska F, Spitalska E, Reiterova K: Immunodiagnostic approaches for the detection of human toxocarosis. Exp Parasitol 2015, 159:252-258.

5.Mohamad S, Azmi NC, Noordin R: Development and evaluation of a sensitive and specific assay for diagnosis of human toxocariasis by use of three recombinant antigens (TES-26, TES-30USM, and TES-120). J Clin Microbiol 2009, 47(6):1712-1717.

6.Gyang PV, Akinwale OP, Lee YL, Chuang TW, Orok AB, Ajibaye O, Liao CW, Chen PC, Chou CM, Huang YC et al: Seroprevalence, disease awareness, and risk factors for Toxocara canis infection among primary schoolchildren in Makoko, an urban slum community in Nigeria. Acta Trop 2015, 146:135-140.

7.Fu CJ, Chuang TW, Lin HS, Wu CH, Liu YC, Langinlur MK, Lu MY, Hsiao WW, Fan CK: Seroepidemiology of Toxocara canis infection among primary schoolchildren in the capital area of the Republic of the Marshall Islands. BMC Infect Dis $2014,14: 261$.

8.Silva MB, Amor ALM, Santos LN, Galvao AA, Oviedo Vera AV, Silva ES, Barbosa CG, Goncalves MS, Cooper PJ, Figueiredo CA et al: Risk factors for Toxocara spp. seroprevalence and its association with atopy and asthma phenotypes in school-age children in a small town and semi-rural areas of Northeast Brazil. Acta Trop 2017, 174:158164.

9.Fan CK, Lan HS, Hung CC, Chung WC, Liao CW, Du WY, Su KE: Seroepidemiology of Toxocara canis infection among mountain aboriginal adults in Taiwan. American Journal of Tropical Medicine and Hygiene 2004, 71(2):216-221.

10.Kaplan M, Kalkan A, Kuk S, Demirdag K, Ozden M, Kilic SS: Toxocara seroprevalence in schizophrenic patients in Turkey. Yonsei Med J 2008, 49(2):224-229.

11.Fajutag AJ, Paller VG: Toxocara egg soil contamination and its seroprevalence among public school children in Los Banos, Laguna, Philippines. Southeast Asian J Trop Med Public Health 2013, 44(4):551-560.

12.Aghamolaie S, Seyyedtabaei SJ, Behniafar H, Foroutan M, Saber V, Hanifehpur H, Mehravar S, Rostami A: Seroepidemiology, modifiable risk factors and clinical symptoms of Toxocara spp. infection in northern Iran. Trans $R$ Soc Trop Med Hyg 2019, 113(3):116-122.

13.Hosseini-Safa A, Mousavi SM, Bahadoran Bagh Badorani M, Ghatreh Samani M, Mostafaei S, Yousofi Darani H: Seroepidemiology of Toxocariasis in Children (5-15 yr Old) Referred to the Pediatric Clinic of Imam Hossein Hospital, Isfahan, Iran. Iran J Parasitol 2015, 10(4):632-637.

14.Liu EW, Chastain HM, Shin SH, Wiegand RE, Kruszon-Moran D, Handali S, Jones JL: Seroprevalence of Antibodies to Toxocara Species in the United States and Associated Risk Factors, 2011-2014. Clin Infect Dis 2018, 66(2):206-212.

15. Nicoletti A, Cicero CE, Mantella A, Giuliano L, Rascuna C, Paradisi V, Bartoloni A, Zappia M, Sofia V: Seroprevalence of Toxocara Canis in the city of Catania, Italy. Mediterr J Hematol Infect Dis 2019, 11(1):e2019031.

16.Papavasilopoulos V, Pitiriga V, Birbas K, Elefsiniotis J, Bonatsos G, Tsakris A: Soil contamination by Toxocara canis and human seroprevalence in the Attica region, Greece. Germs 2018, 8(3):155-161.

17.Sowemimo OA, Lee YL, Asaolu SO, Chuang TW, Akinwale OP, Badejoko BO, Gyang VP, Nwafor T, Henry E, Fan CK: Seroepidemiological study and associated risk factors of Toxocara canis infection among preschool children in Osun

Page $12 / 14$ 
State, Nigeria. Acta Trop 2017, 173:85-89.

18.Romero Nunez C, Mendoza Martinez GD, Yanez Arteaga S, Ponce Macotela M, Bustamante Montes P, Ramirez Duran N: Prevalence and risk factors associated with Toxocara canis infection in children. ScientificWorldJournal 2013, 2013:572089.

19.Martinez M, Garcia H, Figuera L, Gonzalez V, Lamas F, Lopez K, Mijares V, Corrales Y, Lares M, Ferrer E: Seroprevalence and risk factors of toxocariasis in preschool children in Aragua state, Venezuela. Trans $R$ Soc Trop Med Hyg 2015, 109(9):579-588.

20.Pumidonming W, Salman D, Gronsang D, Abdelbaset AE, Sangkaeo K, Kawazu SI, Igarashi M: Prevalence of gastrointestinal helminth parasites of zoonotic significance in dogs and cats in lower Northern Thailand. J Vet Med Sci 2017, 78(12):1779-1784.

21.Rojekittikhun W, Chaisiri K, Mahittikorn A, Pubampen S, Sa-Nguankiat S, Kusolsuk T, Maipanich W, Udonsom R, Mori $\mathrm{H}$ : Gastrointestinal parasites of dogs and cats in a refuge in Nakhon Nayok, Thailand. Southeast Asian J Trop Med Public Health 2014, 45(1):31-39.

22.Punsawad C, Phasuk N, Thongtup K, Nagavirochana S, Viriyavejakul P: Prevalence of parasitic contamination of raw vegetables in Nakhon Si Thammarat province, southern Thailand. BMC Public Health 2019, 19(1):34.

23.Fan CK, Liao CW, Kao TC, Li MH, Du WY, Su KE: Sero-epidemiology of Toxocara canis infection among aboriginal schoolchildren in the mountainous areas of north-eastern Taiwan. Ann Trop Med Parasitol 2005, 99(6):593-600.

24.Lee JY, Yang MH, Hwang JH, Kang M, Paeng JW, Yune S, Lee BJ, Choi DC: The Prevalence of Toxocariasis and Diagnostic Value of Serologic Tests in Asymptomatic Korean Adults. Allergy Asthma Immunol Res 2015, 7(5):467-475.

25.Azam D, Ukpai OM, Said A, Abd-Allah GA, Morgan ER: Temperature and the development and survival of infective Toxocara canis larvae. Parasitol Res 2012, 110(2):649-656.

26.Mendonca LR, Figueiredo CA, Esquivel R, Fiaccone RL, Pontes-de-Carvalho L, Cooper P, Barreto ML, Alcantara-Neves NM: Seroprevalence and risk factors for Toxocara infection in children from an urban large setting in Northeast Brazil. Acta Trop 2013, 128(1):90-95.

27.Berrett AN, Erickson LD, Gale SD, Stone A, Brown BL, Hedges DW: Toxocara Seroprevalence and Associated Risk Factors in the United States. Am J Trop Med Hyg 2017, 97(6):1846-1850.

28.Cassenote AJ, Lima AR, Pinto Neto JM, Rubinsky-Elefant G: Seroprevalence and modifiable risk factors for Toxocara spp. in Brazilian schoolchildren. PLoS Negl Trop Dis 2014, 8(5):e2830.

29.Watthanakulpanich D, Smith HV, Hobbs G, Whalley AJ, Billington D: Application of Toxocara canis excretorysecretory antigens and IgG subclass antibodies (IgG1-4) in serodiagnostic assays of human toxocariasis. Acta Trop 2008, 106(2):90-95.

30.Punsawad C, Phasuk N, Bunratsami S, Thongtup K, Siripakonuaong N, Nongnaul S: Prevalence of intestinal parasitic infection and associated risk factors among village health volunteers in rural communities of southern Thailand. BMC Public Health 2017, 17(1):564.

31.Punsawad C, Phasuk N, Bunratsami S, Thongtup K, Viriyavejakul P, Palipoch S, Koomhin P, Nongnaul S: Prevalence of intestinal parasitic infections and associated risk factors for hookworm infections among primary schoolchildren in 


\section{Figures}

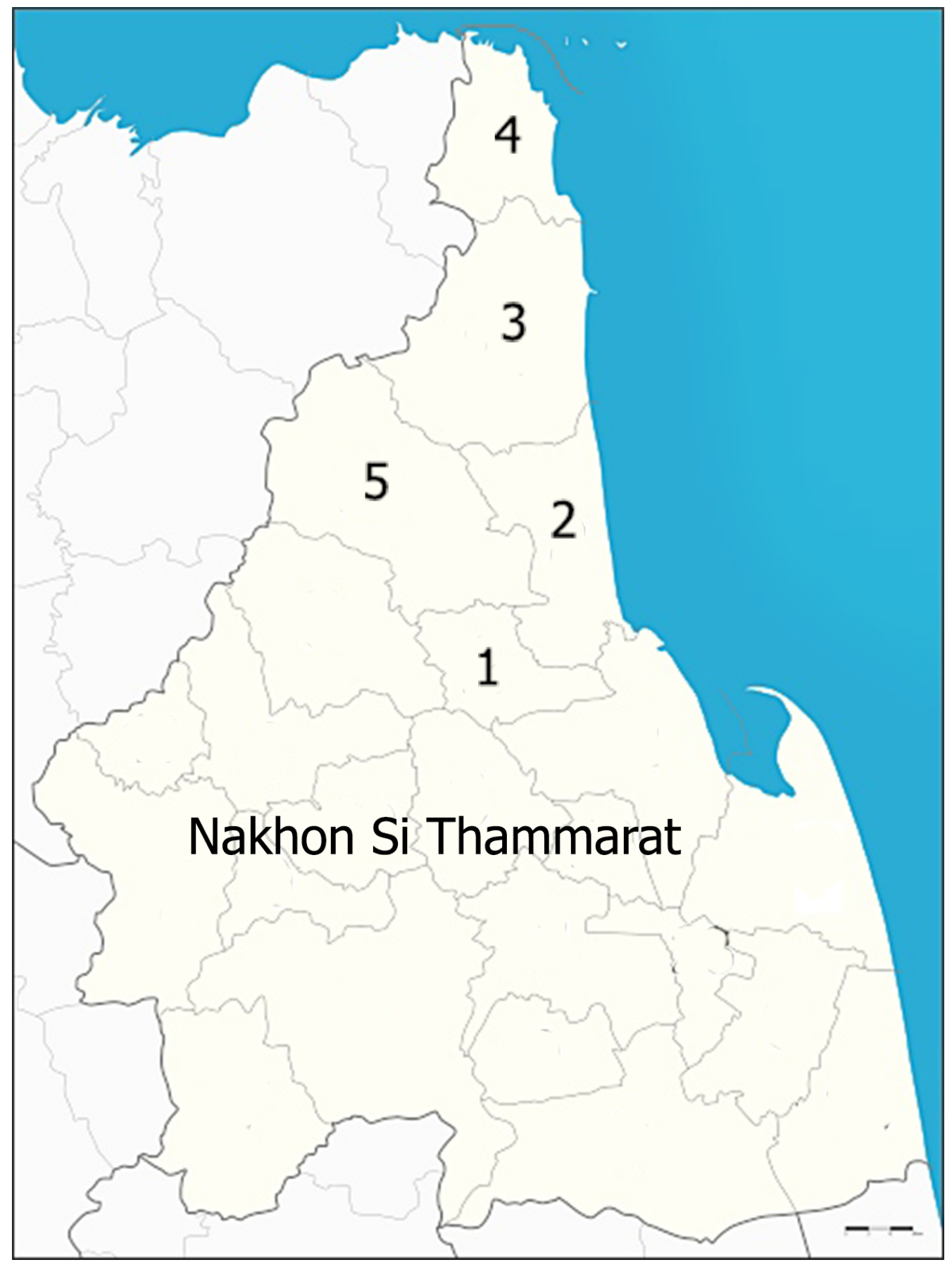

\section{Figure 1}

Map of Phrom Khiri (1), Tha Sala (2), Sichon (3), Khanom (4) and Nopphitam (5) Districts, Nakhon Si Thammarat Province, southern Thailand. (Map from Wikimedia Commons:

https://commons.m.wikimedia.org/wiki/Atlas_of_Thailand\#) 